\title{
IMPORTANCE OF MIGRATORY BIRDS AS A VECTOR IN SPREADING OF SALMONELLA IN EGYPT IN THE PERIOD FROM NOVEMBER 2017 TO MARCH 2018
}

\author{
NEHAL, M. NABIL ${ }^{1}$ and AHLAM, E. YONIS ${ }^{2}$ \\ ${ }^{1}$ Reference Laboratory for Veterinary Quality Control on Poultry Production-Dakahlia \\ Branch- (Gamasa), Animal Health Research Institute. \\ ${ }^{2}$ Reference Laboratory for Veterinary Quality Control on Poultry Production-Damanhour \\ Branch, Animal Health Research Institute
}

Received: 31 March 2019; Accepted: 7 April 2019

\begin{abstract}
Migratory birds play a significant role in the ecology, circulation and transmission of zoonotic pathogens specially Salmonella that producing animal and human illnesses in addition to sever economic losses to poultry industry, so that the prevalence of Salmonella was estimated and studied from six species of migratory waterfowl birds along Manzala Lake in Dakahlia and Damietta Governorates, Egypt during the period from November 2017 to March 2018. A total of 100 live birds were collected from hunters and the internal organs of those birds were subjected to bacteriological examinations, antimicrobial susceptibility testing and molecular detection of some virulence genes. Seven Salmonella isolates were isolated with a percentage of 7\%, (7 out of 100) from Common Teal, Mallard ducks and Shoveler birds. Four different serotypes across the study sites were identified; $S$. Typhimurium, $S$. Bardo, $S$. Montevideo and $S$. Kentucky. All Salmonella isolates showed high sensitivity to Streptomycin, Erythromycin, Norfloxacin, Colistin sulphat and Doxycycline. Two $S$. Bardo isolates, $S$. Typhimurium, $S$. Kentucky showed multi- drug resistance. $S$. Montevideo and $2 \mathrm{~S}$. Bardo isolates showed higher sensitivity to most of the used antimicrobial agents. Seven virulence genes $(i n v \mathrm{~A}, \operatorname{sop} \mathrm{B}, m g t \mathrm{C}, b c f \mathrm{C}$, $s p v \mathrm{C}, \operatorname{fim} \mathrm{H}$ and $\operatorname{fim} \mathrm{A}$ ) were detected using Polymerase Chain Reaction technique (PCR) in all of the examined Salmonella isolates.
\end{abstract}

Key words: Migratory birds, Salmonella, virulence genes, antimicrobial susceptibility.

\section{INTRODUCTION}

Migratory birds travel across national and international borders; they can transfer microorganisms across the world and play a significant role in the ecology and circulation of pathogenic organisms (Georgopoulou and Tsiouris, 2008), those birds considered as long-distance vectors for a wide range of microorganisms (Nuttall, 1997). It can carry zoonotic pathogens, including enteric pathogenic bacteria, either being themselves diseased or being carriers (Abulreesh et al., 2007) and implicated in the transmission of zoonoses and other microbial pathogen by three mechanisms: mechanical carriers, biological carriers and carriers of infected ectoparasites (Jourdain et al., 2007), the mode of transmission can be directly through bird its self or indirectly through arthropods, soil, food and water

Corresponding author: Dr. NEHAL, M. NABIL

E-mail address: nehal_nabil84@yahoo.com

Present address: Reference Laboratory for Veterinary Quality Control on Poultry Production-Dakahlia Branch- (Gamasa), Animal Health Research Institute
(Hubalek, 2004). Also it plays a significant role in the epidemiology of enteric zoonotic bacteria including Escherichia coli and Salmonella (Tsiodras et al., 2008). It also involved in the dissemination of Salmonella to human or other domestic animals and birds (Millán et al., 2004).

Several birds are migrating to Egypt in winter season such as Coot (Fulica atra), Teal (Anas crecca), Shoveler (Anas clypeata), Pintail (Anas Acuta), Wigeon (Anas Penelope) and Mallard (Anas Platyrbynchos) (Goodman and Meininger, 1989). Common Coot (Fulica atra) birds are distrusted in whole Eurasia and Northern Africa. Most of those birds stay in central and Western Europe, but some continue as far south as North Africa (Delany et al., 2006), those birds are common breeding resident on larger lakes of Nile Delta (Egypt), also it considered as abundant winter visitor from mid-September, large number of this species present in mid-winter and by mid-March and most Coots leave Egypt (Goodman and Meininger, 1989).

Common Teal (Anas crecca) birds migrated from Western Eurasia toward North Africa (Scott and 
Rose, 1996). In Egypt Teal birds are common migrants and winter visitor to land waters on Nile Delta lakes, Lake Qarun (Egypt) and along the Nile from early September to late April (Goodman and Meininger, 1989).

Shoveler (Anas clypeata) birds migrated from SWSiberia in autumn toward Egypt (Scott and Rose, 1996), (McClure, 1998) and (Veen et al., 2005) and considered as common passage migrant throughout Egypt from late August to late May but rare in summer. Small flocks have been recorded along north coast of Sinai in September and October (Baha el Din and Salama, 1984) but this species are regular visitor to all inland waters as lakes (Manzala, Burullus and Qarun) (Meininger and Mullie, 1981).

Pintail (Anas Acuta) birds migrated to Egypt from SW-Siberia in winter (McClure, 1998) and (Veen et $a l ., 2005)$ and move in winter from Russia, western and central Siberia via Egypt toward Netherlands, France, Great Britain North Africa and Senegal delta (Scott and Rose, 1996) and (Wernham et al., 2002), other birds migrated to Egypt from Netherlands (McClure, 1998). In Egypt, Pintail birds are winter visitor and migrate with large number in autumn throughout the country, this autumn passage continues into December along north coast of Sinai, Nile Delta. Wigeon birds also considered as winter visitor to most inland waters as Nile Delta lakes, lake Qarun, lake Bardawil and Nile valley (Goodman and Meininger, 1989).

Wigeon (Anas Penelope) birds migrated in winter from West and Central Siberia toward North-Africa (Bianki and Dobrynina, 1997). In Egypt, Wigeon birds considered as winter visitor to most inland waters as Nile Delta lakes, lake Qarun, lake Bardawil and Nile valley (Goodman and Meininger, 1989).

Mallard (Anas Platyrbynchos) birds distributed in Czechoslovakia, S-European and Russia move in winter to North Africa, Italy and Germany (McClure, 1998).

Bacteria of the genus Salmonella colonize the digestive tract of birds, mammals and reptiles (Silva et al., 2010), producing gastroenteritis in humans leading to economic losses, animal and human illnesses (Hilbert et al., 2012), affecting poultry industry and causing reduced production (Lutful Kabir, 2010). Salmonella commonly found in the intestinal tract of wild birds (Tsiodras et al., 2008) and it can be introduced into poultry houses via free flying wild birds. The infected birds may transmit infection directly or indirectly via infecting pets and food animals (Tizard, 2004).

Salmonella is Gram negative, non- spore forming bacteria, usually motile and belongs to the family of Enterobacteriaceae (Bennasar et al., 2000). It's a facultative intracellular pathogen causing localized, systemic infections and chronic asymptomatic carrier state (Su et al., 2011). Signs of paratyphoid infection in all species of young poultry include closed eyes, droopy wings, ruffled feathers, anorexia and profuse watery diarrhea with pasted vent (Gast and Beard, 1992). The postmortem findings are enteritis, necrosis in mucosal wall of small intestine, enlarged liver with necrotic foci and cheesy cecal cores (Hoop and Pospischill, 1993).

\section{Aim of study}

This study was undertaken to estimate the incidence of Salmonella isolated from migratory birds and to identify the role of those birds as a vector in the spreading of drug-resistant Salmonellae during the period from November 2017 to March 2018 in Dakahlia and Damietta Governorates.

\section{MATERIALS AND METHODS}

\section{Sampling strategy}

A total of 100 live migratory birds from different locations along Manzala Lake in Dakahlia and Damietta Governorates, Egypt were collected from hunters during the period from mid- November 2017 to late- March 2018. The species scientific names, English names and local names in Egypt according to Goodman and Meininger, (1989) were listed in (Table, 1). All of the collected birds were transported to Reference Laboratory for Veterinary Quality Control on Poultry Production (Gamasa lab.Dakahlia branch), Animal Health Research Institute, then humanly sacrificed and subjected to postmortem examinations. A total of 500 internal organs form 100 birds (liver, cecum, spleen, lung and heart) were collected aseptically and processed for further examinations. 
Table 1: Number, species and localities of the collected migratory birds.

\begin{tabular}{|c|c|c|c|c|c|}
\hline \multicolumn{3}{|c|}{ Species } & \multirow{2}{*}{$\begin{array}{l}\text { Total number } \\
\text { (100 birds) }\end{array}$} & \multicolumn{2}{|c|}{ Localities and No. of birds } \\
\hline Scientific name & English name & $\begin{array}{c}\text { Local name in } \\
\text { Egypt }\end{array}$ & & Governorate & Number \\
\hline \multirow{2}{*}{ Anas clypeata } & \multirow{2}{*}{ Shoveler } & \multirow{2}{*}{ Kiish } & \multirow[t]{2}{*}{6} & Dakahlia & 0 \\
\hline & & & & Damietta & 6 \\
\hline \multirow{2}{*}{ Anas crecca } & \multirow{2}{*}{ Common Teal } & \multirow{2}{*}{ Sharshiir } & \multirow[t]{2}{*}{60} & Dakahlia & 55 \\
\hline & & & & Damietta & 5 \\
\hline \multirow{2}{*}{ Anas acuta } & \multirow{2}{*}{ Pintail } & \multirow[t]{2}{*}{ Balbuul } & \multirow[t]{2}{*}{11} & Dakahlia & 0 \\
\hline & & & & Damietta & 11 \\
\hline \multirow{2}{*}{$\begin{array}{c}\text { Anas } \\
\text { platyrhynchos }\end{array}$} & \multirow{2}{*}{ Mallard } & \multirow{2}{*}{ Khudaarii } & \multirow[t]{2}{*}{14} & Dakahlia & 0 \\
\hline & & & & Damietta & 14 \\
\hline \multirow{2}{*}{ Fulica atra } & \multirow{2}{*}{ Common Coot } & \multirow{2}{*}{ Ghurr } & \multirow[t]{2}{*}{4} & Dakahlia & 2 \\
\hline & & & & Damietta & 2 \\
\hline \multirow{2}{*}{ Anas penelope } & \multirow{2}{*}{ Wigeon } & \multirow{2}{*}{ Siwwaay } & \multirow[t]{2}{*}{5} & Dakahlia & 0 \\
\hline & & & & Damietta & 5 \\
\hline
\end{tabular}

Salmonella isolation, identification and serotyping Liver, cecum, spleen, lung and heart from each bird were pooled together as a one sample and then subjected to Salmonella isolation and identification according to ISO 6579 (2017) as follow: Samples were pre-enriched into buffered peptone water with a dilution $(1: 10)$ and incubated at $37^{\circ} \mathrm{C}$ for 18 hours. A total of $0.1 \mathrm{ml}$ of the pre-enriched broth was transferred into a tube containing $10 \mathrm{ml}$ of RappaportVassiliadis medium with soya and incubated at $41.5^{\circ} \mathrm{C}$ for 24 hours. Another $1 \mathrm{ml}$ of the preenrichment broth was transferred into a tube containing $10 \mathrm{ml}$ of Muller-Kauffmann tetrathionate novobiocin broth and incubated at $37^{\circ} \mathrm{C}$ for 24 hours. A loop-full from each broth was streaked separately onto (Xylose Lysine Deoxycholate, Hektoen Enteric, MacConkey's and S S) agar plates and incubated at $37^{\circ} \mathrm{C}$ for 24 hours then checked for growth of typical Salmonella colonies. The isolates that were biochemically identified as Salmonella were serologically identified according to Kauffman- white scheme (Kauffman, 1974) for determining somatic (O) and flagellar $(\mathrm{H})$ antigens (Cruickshank et al., 1975) and (WHO, 2007).

\section{Antimicrobial susceptibility testing}

Antimicrobial susceptibility testing was performed using agar disc diffusion method on Muller Hinton agar plates according to Finegold and Martin (1982). In brief, one colony from cultured plates of each Salmonella isolate was suspend into $5 \mathrm{ml}$ Mueller Hinton broth and incubated at $37^{\circ} \mathrm{C}$ for $2-8$ hours until turbidity was seen. The turbidity was adjusted by careful dilution to be equivalent to a 0.5 McFarland's standard. A sterile swab was dipped into the Mueller Hinton broth then streaked onto a Mueller Hinton agar plate, and then the antimicrobial discs were arranged by using sterilized forceps at least $15 \mathrm{~mm}$ distance from the edge of the plate and apart from each other.

The antimicrobial agents that used were: Ciprofloxacin $(5 \mu \mathrm{g})$, Enrofloxacin $(5 \mu \mathrm{g})$, Norfloxacin
$(10 \mu \mathrm{g})$, Levofloxacin $(25 \mu \mathrm{g})$, Ampicillin - sulbactam $(20 \mu \mathrm{g})$, Tetracycline $(30 \mu \mathrm{g})$, Doxycyclin $(30 \mu \mathrm{g})$, Erythromycin $(15 \mu \mathrm{g}) \quad$ Streptomycin $\quad(10 \mu \mathrm{g})$, Neomycin $(30 \mu \mathrm{g})$ and Colistin sulphate $(25 \mu \mathrm{g})$. The Mueller Hinton plates were incubated at $37{ }^{\circ} \mathrm{C} /$ overnight. The diameters of the inhibition zones were measured and the antimicrobial agents were categorized into susceptible, intermediate and resistant categories according to (CLSI, 2016).

Molecular detection of Salmonella virulence genes DNA was extracted from Salmonella isolates using QIAamp DNA Mini kit (Qiagen, Germany, GmbH) with modifications from the manufacturer's recommendations. Briefly, $200 \mu \mathrm{l}$ of samples suspension incubated with $10 \mu \mathrm{l}$ of proteinase $\mathrm{K}$ and $200 \mu \mathrm{l}$ of lysis buffer at $56^{\circ} \mathrm{C}$ for 10 minutes. Then $200 \mu \mathrm{l}$ of $100 \%$ ethanol was added to the lysate. The samples then washed and centrifuged. Nucleic acid was eluted with $100 \mu 1$ of elution buffer.

The oligonucleotide primers that used were provided from Metabion (Germany) listed in table (2); Primers were utilized in a $25 \mu 1$ reaction containing $12.5 \mu 1$ of Emerald AMP Max PCR master mix (Takara, Japan), $1 \mu \mathrm{l}$ of each primer of $20 \mathrm{pmol}$ concentrations, $4.5 \mu \mathrm{l}$ of water and $6 \mu 1$ of DNA template. The reaction was performed in a thermal cycler (T3, Biometra).

After that the PCR products were separated by electrophoresis on (1.5\%) agarose gel (Applichem, Germany, GmbH) in $1 \mathrm{x}$ TBE buffer at room temperature using gradients of $5 \mathrm{~V} / \mathrm{cm}$. For gel analysis, $20 \mu \mathrm{l}$ of the products was loaded in each gel slot. A gelpilot 100 bp DNA Ladder (Qiagen, Germany, GmbH) and gene ruler $50 \mathrm{bp}, 100 \mathrm{bp}$ ladders (Fermentas, Thermo) were used to determine the fragment sizes. The gel was photographed by a gel documentation system (Alpha Innotech, Biometra) and the data were analyzed through computer software (Automatic image capture software, protein simple formerly cell, Bioscience, UAS). 
Table 2: Oligonucleotide primers sequences, target genes, and cycling conditions.

\begin{tabular}{|c|c|c|c|c|c|c|c|c|}
\hline \multirow[b]{2}{*}{$\begin{array}{l}\text { Target } \\
\text { gene }\end{array}$} & \multirow{2}{*}{$\begin{array}{c}\text { Primers } \\
\text { sequences }\end{array}$} & \multirow[b]{2}{*}{$\begin{array}{l}\text { Seg. } \\
\text { (bp) }\end{array}$} & \multirow[b]{2}{*}{ P. dent. } & \multicolumn{3}{|c|}{ Amplification (35 cycles) } & \multirow[b]{2}{*}{ Final ext. } & \multirow[b]{2}{*}{ Reference } \\
\hline & & & & $\begin{array}{c}\text { Sec. } \\
\text { dent. }\end{array}$ & Annealing & Ext. & & \\
\hline $\operatorname{inv} \mathrm{A}$ & $\begin{array}{c}\text { GTGAAATTA } \\
\text { TCGCCACGTT } \\
\text { CGGGCAA } \\
\text { TCATCGCAC } \\
\text { CGTCAAAGG } \\
\text { AACC }\end{array}$ & 284 & $\begin{array}{c}94^{\circ} \mathrm{C} \\
5 \mathrm{~min} .\end{array}$ & $\begin{array}{c}94^{\circ} \mathrm{C} \\
30 \mathrm{sec} .\end{array}$ & $\begin{array}{c}55^{\circ} \mathrm{C} \\
30 \mathrm{sec} .\end{array}$ & $\begin{array}{c}72^{\circ} \mathrm{C} \\
30 \mathrm{sec} .\end{array}$ & $\begin{array}{c}72^{\circ} \mathrm{C} \\
10 \mathrm{~min} .\end{array}$ & $\begin{array}{c}\text { Oliveira et } \\
\text { al., } 2003\end{array}$ \\
\hline $\operatorname{sop} \mathrm{B}$ & $\begin{array}{c}\text { TCA GAA } \\
\text { GRC GTC TAA } \\
\text { CCA CTC } \\
\text { TAC CGT CCT } \\
\text { CAT GCA CAC } \\
\text { TC }\end{array}$ & 517 & $\begin{array}{l}94^{\circ} \mathrm{C} \\
5 \mathrm{~min} .\end{array}$ & $\begin{array}{c}94^{\circ} \mathrm{C} \\
30 \mathrm{sec} .\end{array}$ & $\begin{array}{c}58^{\circ} \mathrm{C} \\
40 \mathrm{sec} .\end{array}$ & $\begin{array}{c}72^{\circ} \mathrm{C} \\
45 \mathrm{sec} .\end{array}$ & $\begin{array}{c}72^{\circ} \mathrm{C} \\
10 \mathrm{~min} .\end{array}$ & \\
\hline$m g t \mathrm{C}$ & $\begin{array}{c}\text { TGA CTA TCA } \\
\text { ATG CTC CAG } \\
\text { TGA AT } \\
\text { ATT TAC TGG } \\
\text { CCG CTA TGC } \\
\text { TGT TG }\end{array}$ & 677 & $\begin{array}{c}94^{\circ} \mathrm{C} \\
5 \mathrm{~min} .\end{array}$ & $\begin{array}{c}94^{\circ} \mathrm{C} \\
30 \mathrm{sec} .\end{array}$ & $\begin{array}{c}58^{\circ} \mathrm{C} \\
40 \mathrm{sec} .\end{array}$ & $\begin{array}{c}72^{\circ} \mathrm{C} \\
45 \mathrm{sec} .\end{array}$ & $\begin{array}{c}72^{\circ} \mathrm{C} \\
10 \mathrm{~min} .\end{array}$ & Huehn et \\
\hline$b c f \mathrm{C}$ & $\begin{array}{c}\text { ACC AGA } \\
\text { GAC ATT GCC } \\
\text { TTC C } \\
\text { TTC TGC TCG } \\
\text { CCG CTA TTC } \\
\text { G }\end{array}$ & 467 & $\begin{array}{c}94^{\circ} \mathrm{C} \\
5 \mathrm{~min} .\end{array}$ & $\begin{array}{c}94^{\circ} \mathrm{C} \\
30 \mathrm{sec} .\end{array}$ & $\begin{array}{c}53^{\circ} \mathrm{C} \\
40 \mathrm{sec} .\end{array}$ & $\begin{array}{c}72^{\circ} \mathrm{C} \\
45 \mathrm{sec} .\end{array}$ & $\begin{array}{c}72^{\circ} \mathrm{C} \\
10 \mathrm{~min} .\end{array}$ & \\
\hline$s p \nu \mathrm{C}$ & $\begin{array}{c}\text { ACCAGAGAC } \\
\text { ATTGCCTTC } \\
\mathrm{C} \\
\text { TTCTGATCGC } \\
\text { CGCTATTC G }\end{array}$ & 467 & $\begin{array}{c}94^{\circ} \mathrm{C} \\
5 \mathrm{~min} .\end{array}$ & $\begin{array}{c}94^{\circ} \mathrm{C} \\
30 \mathrm{sec} .\end{array}$ & $\begin{array}{c}58^{\circ} \mathrm{C} \\
40 \mathrm{sec} .\end{array}$ & $\begin{array}{c}72^{\circ} \mathrm{C} \\
45 \mathrm{sec} .\end{array}$ & $\begin{array}{c}72^{\circ} \mathrm{C} \\
10 \mathrm{~min} .\end{array}$ & \\
\hline $\operatorname{fim} \mathrm{H}$ & $\begin{array}{c}\text { GTGCCAATT } \\
\text { CCTCTTACCG } \\
\text { TT } \\
\text { TGGAATAAT } \\
\text { CGTACCGTT } \\
\text { GCG }\end{array}$ & 164 & $\begin{array}{c}94^{\circ} \mathrm{C} \\
5 \mathrm{~min} .\end{array}$ & $\begin{array}{c}94^{\circ} \mathrm{C} \\
30 \mathrm{sec} .\end{array}$ & $\begin{array}{c}59^{\circ} \mathrm{C} \\
30 \mathrm{sec} .\end{array}$ & $\begin{array}{c}72^{\circ} \mathrm{C} \\
30 \mathrm{sec} .\end{array}$ & $\begin{array}{c}72^{\circ} \mathrm{C} \\
7 \mathrm{~min} .\end{array}$ & $\begin{array}{l}\text { Hojati et } \\
\text { al., } 2013\end{array}$ \\
\hline fim A & $\begin{array}{c}\text { CCT TTC TCC } \\
\text { ATC GTC CTG } \\
\text { AA } \\
\text { TGG TGT TAT } \\
\text { CTG CCT GAC } \\
\text { CA }\end{array}$ & 85 & $\begin{array}{c}94^{\circ} \mathrm{C} \\
5 \mathrm{~min} .\end{array}$ & $\begin{array}{c}94^{\circ} \mathrm{C} \\
30 \mathrm{sec} .\end{array}$ & $\begin{array}{c}50^{\circ} \mathrm{C} \\
30 \mathrm{sec} .\end{array}$ & $\begin{array}{c}72^{\circ} \mathrm{C} \\
30 \mathrm{sec} .\end{array}$ & $\begin{array}{l}72^{\circ} \mathrm{C} \\
7 \mathrm{~min} .\end{array}$ & $\begin{array}{c}\text { Cohen } e t \\
\text { al.1996 }\end{array}$ \\
\hline
\end{tabular}

Seg. $(b p)=$ amplified segment\& $\mathrm{P}$. dent. $=$ primary denaturation $\&$ Sec. denat. $=$ secondary denaturation $\&$ Extens $=$ extension\& Final ext.= final extension

\section{RESULTS}

Cultural and biochemical characteristics of the isolated Salmonellae

Cultural and biochemical characteristics of the isolated Salmonellae were similar to that recorded in OIE, (2004). Salmonella fermented dextrose, maltose, and mannitol with acid and gas production. Methyl red, citrate utilization and triple sugar iron tests were positive but Voges-proskauer, urease and indole tests were negative.
Incidence of Salmonella isolation and serotyping results from different migratory birds

A total of 7 Salmonella isolates were reported from 100 migratory birds that collected along Manzala Lake in Dakahlia and Damietta Governorates with an incidence of $(7 \%) ; 5$ Salmonella isolates from Common Teal with a percentage of $(5 / 60)(8.3 \%)$, one isolate from Mallard duck with a percentage of (1/14) $(7.1 \%)$ and one isolate from Shoveler with a percentage of (1/6) (16.6\%). Pintail, Common Coot 
and Wigeon birds were negative for Salmonella detection.

Four different serovars across study sites were reported ( $S$. Typhimurium, $S$. Bardo, S. Montevideo and $S$. Kentucky). Along Manzala Lake at Dakahlia
Governorates; $4 S$. Bardo isolates were recorded from the collected Common Teal birds. However along the lake at Damietta Governorate, 3 Salmonella isolates were recorded; one $S$. Montevideo from Common Teal birds, one S.Typhimurium from Shoveler birds and one $S$. Kentucky from Mallard ducks (Table, 3 ).

Table 3: Serotyping of Salmonellae and percentage of isolate per species.

\begin{tabular}{ccccc}
\hline Location & Species of bird & No. and \% of Salmonella isolates & Serotype \\
\hline Dakahlia & Common Teal & 4 & $(4 / 55)(7.3 \%)$ & $S$. Bardo \\
\hline \multirow{3}{*}{ Damietta } & Common Teal & 1 & $(1 / 5)(20 \%)$ & $S$. Montevideo \\
\cline { 2 - 5 } & Mallard & 1 & $(1 / 14)(7.1 \%)$ & $S$. Kentucky \\
\cline { 2 - 5 } & Shoveler & 1 & $(1 / 6)(16.7 \%)$ & $S$. Typhimurium \\
\hline
\end{tabular}

\section{Antimicrobial Susceptibility pattern}

Characterization of the isolated Salmonellae based on the multiple antimicrobial resistances was an important issue in this study since these results indicated that Salmonella plays an important role as reservoirs of multi-drug resistant bacteria. All Salmonella isolates in this study showed high

sensitivity to Streptomycin, Erythromycin, Norfloxacin, Colistin sulphat and Doxycycline. Two S. Bardo isolates, S. Typhimurium, S. Kentucky showed multi- drug resistance. $S$. Montevideo and 2 S. Bardo isolates showed higher sensitivity to most of the used antimicrobial agents (Table, 4 and 5).

Table 4: Antimicrobial Susceptibility pattern of isolated Salmonellae.

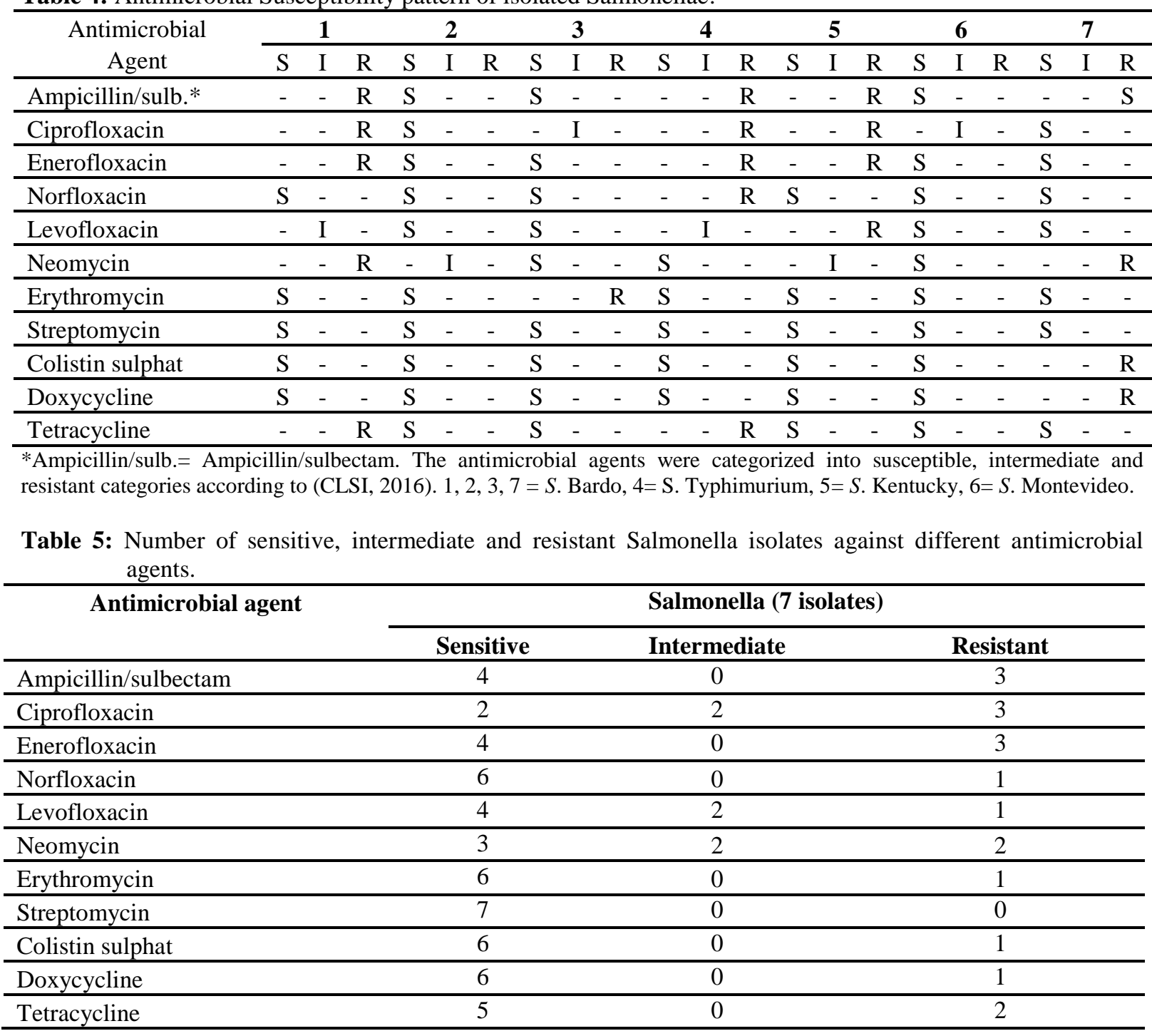


PCR technique results for detection of $i n v \mathrm{~A}, \operatorname{sop} \mathrm{B}$, $m g t \mathrm{C}, b c f \mathrm{C}, \boldsymbol{s p v} \mathrm{C}, \operatorname{fim} \mathrm{H}$ and $f i m \mathrm{~A}$ virulence genes in the examined Salmonella isolates.

PCR was a good tool for accurate detection of several virulence genes such as $i n v \mathrm{~A}, \operatorname{sop} \mathrm{B}, m g t \mathrm{C}, b c f \mathrm{C}$, $s p \nu \mathrm{C}$, fim $\mathrm{H}$ and $f i m \mathrm{~A}$ in the examined Salmonella isolates. All of the examined genes were recorded in all isolates (figure 1, 2, 3, 4, 5, 6 and 7).

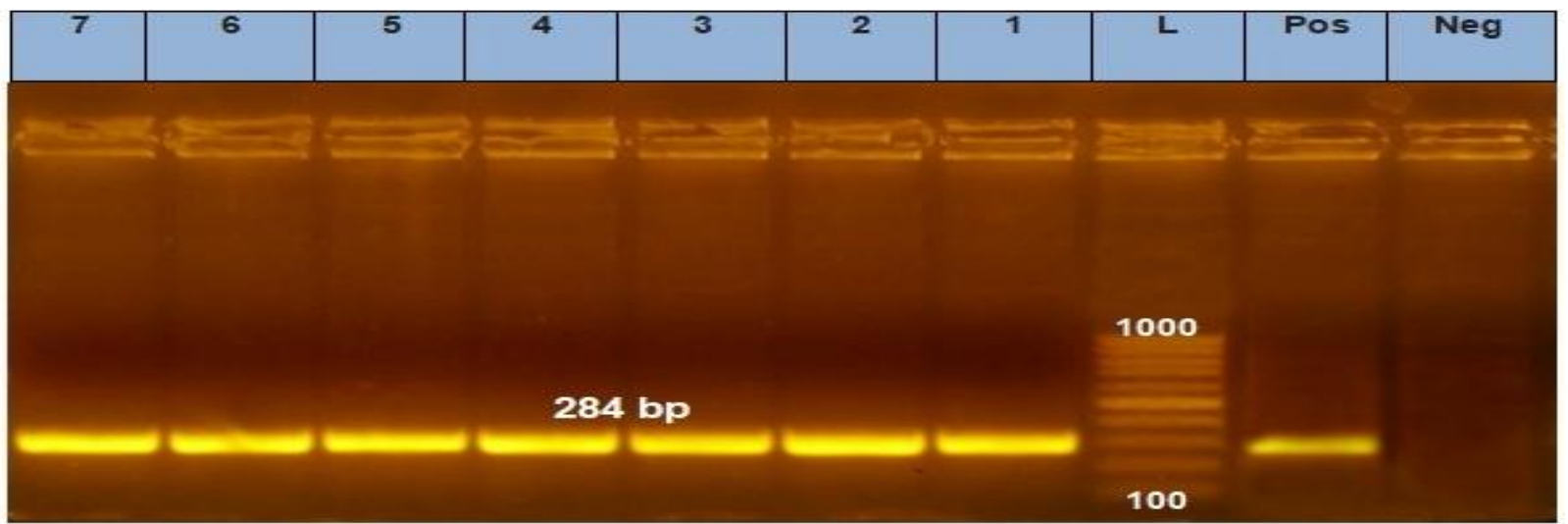

Figure (1): Agarose gel electrophoresis of PCR products for Salmonella isolates to detect invA gene in genomic DNA. Lane L: 100-1000 bp DNA ladder. Neg: Negative control, Pos: Positive control. Lanes: 1 to 7 were positive samples.

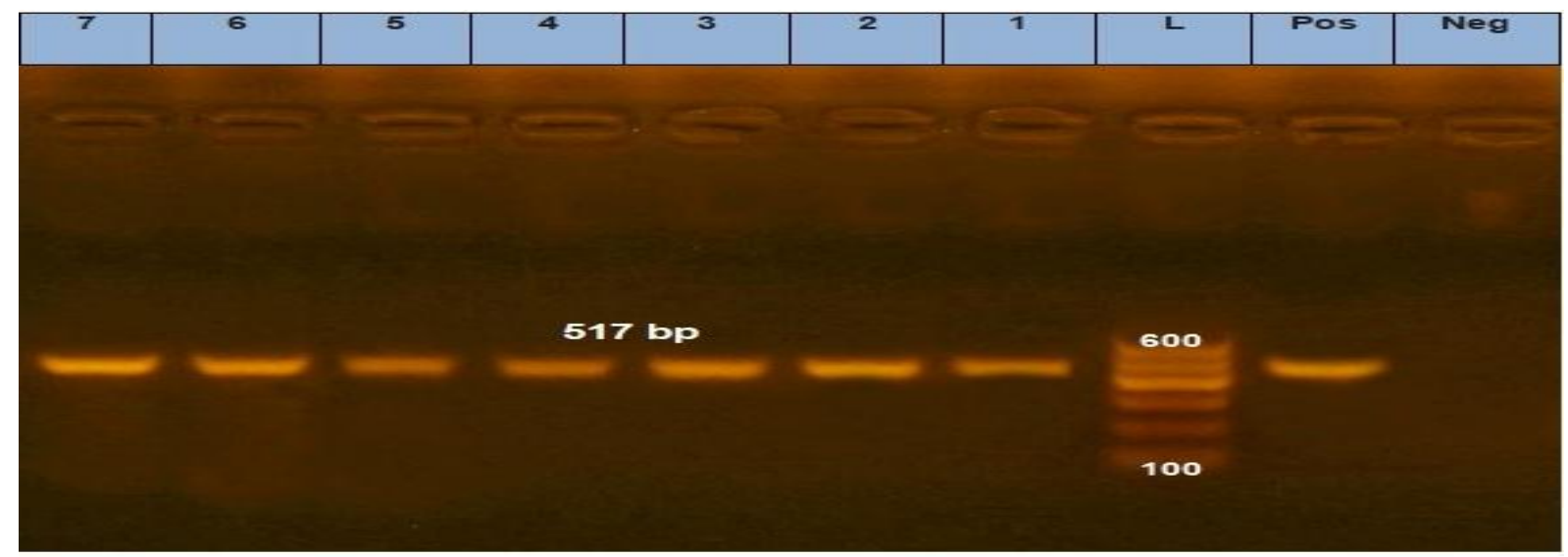

Figure (2): Agarose gel electrophoresis of PCR products for Salmonella isolates to detect sopB gene in genomic DNA. Lane L: 100-600 bp DNA ladder. Neg: Negative control, Pos: Positive control. Lanes: 1 to 7 were positive samples.

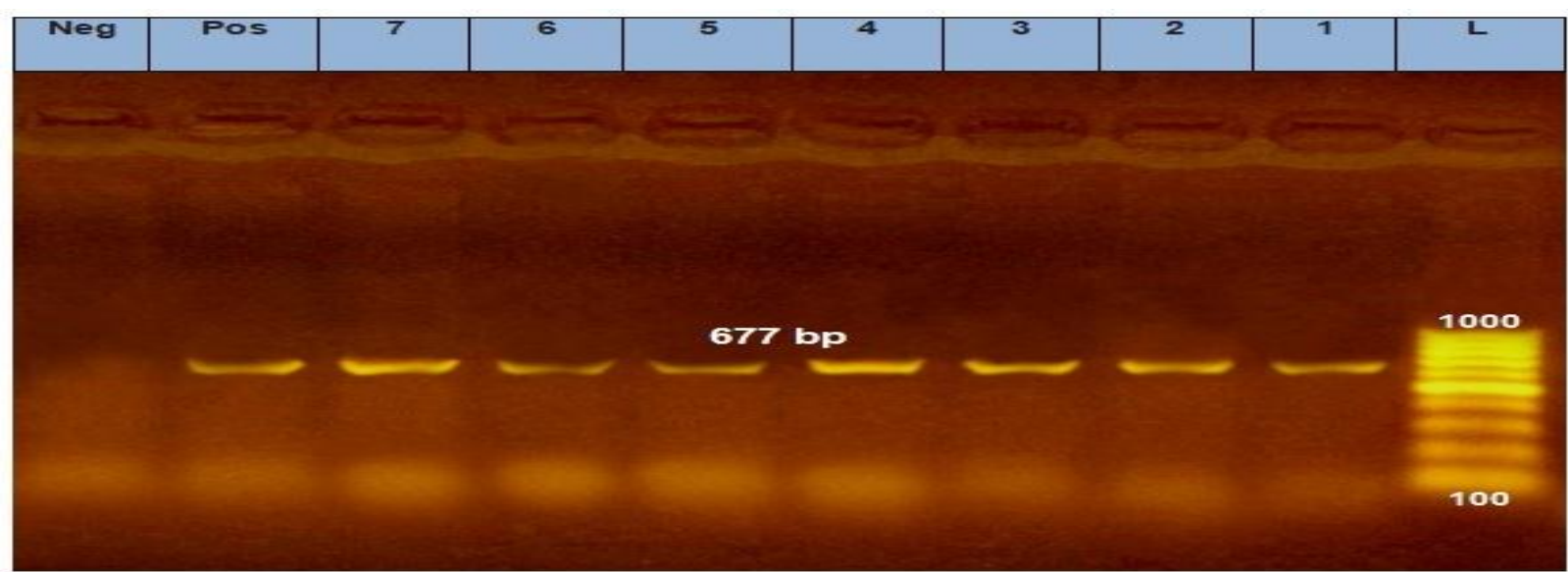

Figure (3): Agarose gel electrophoresis of PCR products for Salmonella isolates to detect $m g t C$ gene in genomic DNA. Lane L: 100-1000 bp DNA ladder. Neg: Negative control, Pos: Positive control. Lanes: 1 to 7 were positive samples. 


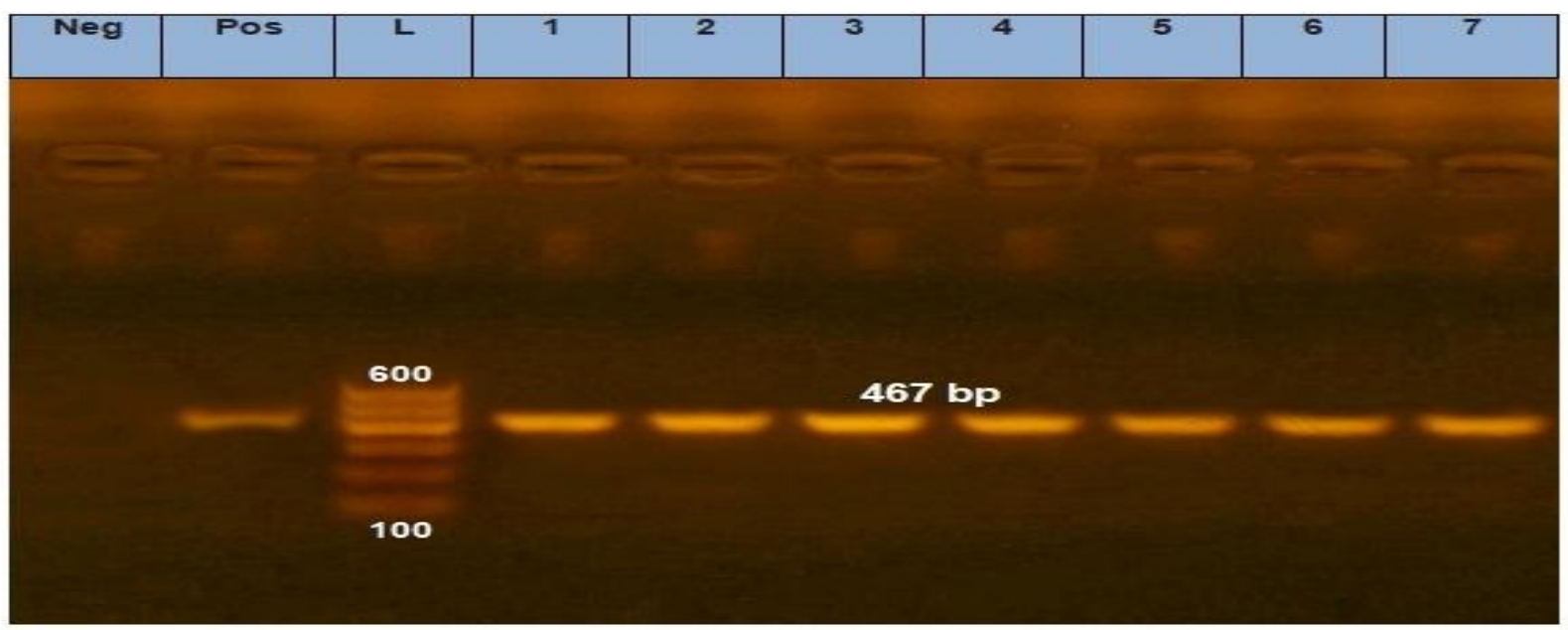

Figure (4): Agarose gel electrophoresis of PCR products for Salmonella isolates to detect $s p v C$ gene in genomic DNA. Lane L: 100-600 bp DNA ladder. Neg: Negative control, Pos: Positive control. Lanes: 1 to 7 were positive samples.

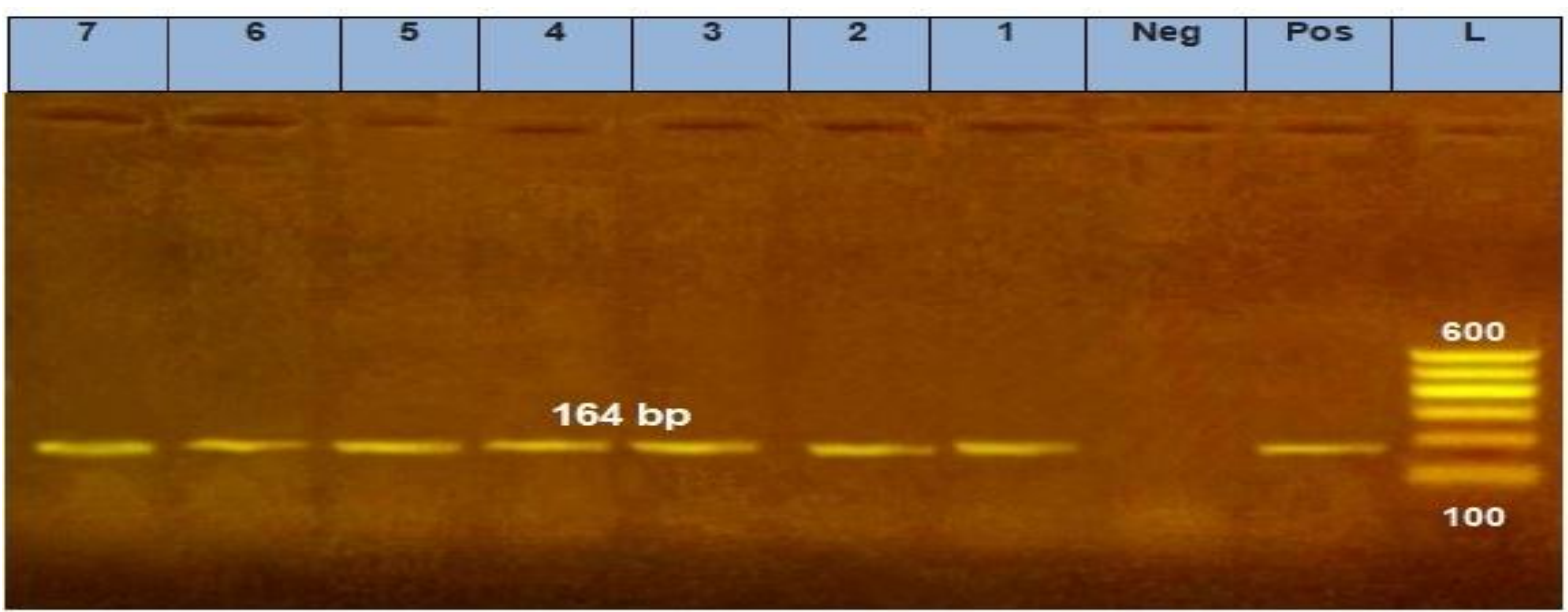

Figure (5): Agarose gel electrophoresis of PCR products for Salmonella isolates to detect fim $\mathrm{H}$ gene in genomic DNA. Lane L: 100-600 bp DNA ladder. Neg: Negative control, Pos: Positive control. Lanes: 1 to 7 were positive samples.

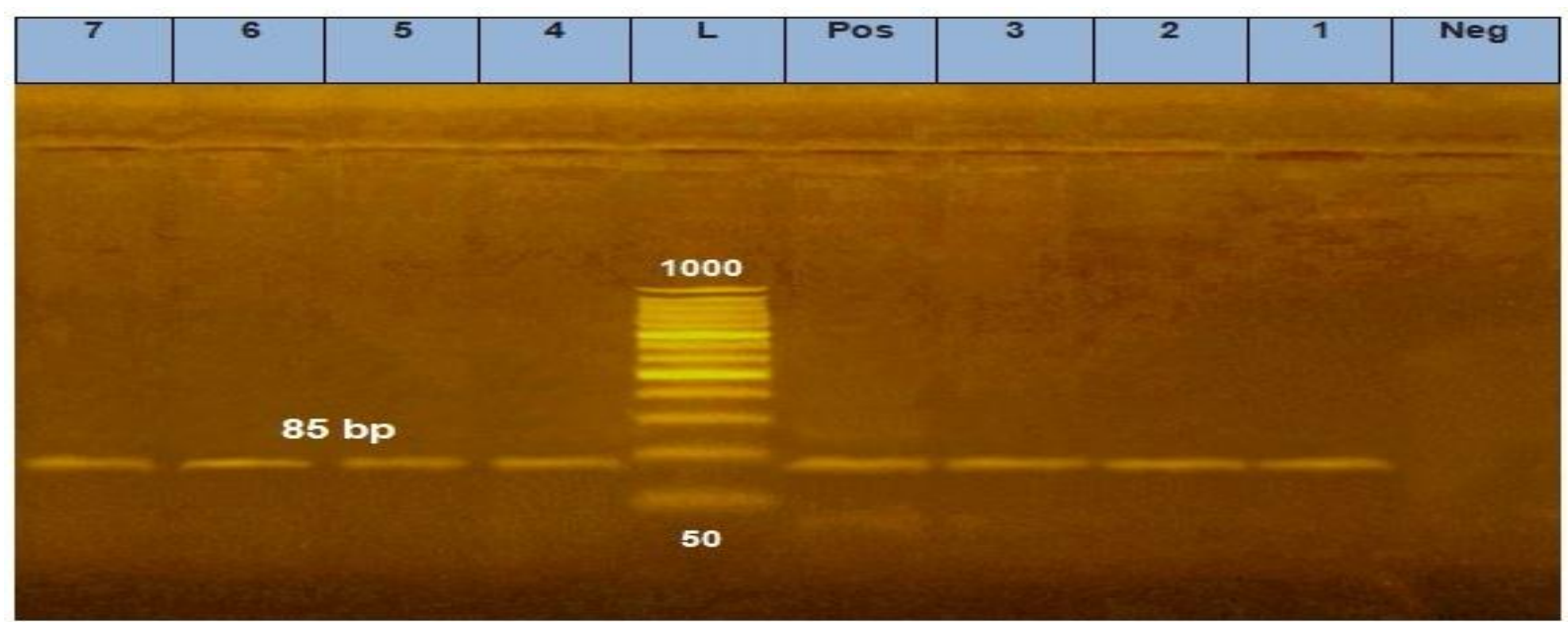

Figure (6): Agarose gel electrophoresis of PCR products for Salmonella isolates to detect fimA gene in genomic DNA. Lane L: gene ruler 50 bp DNA ladder. Neg: Negative control, Pos: Positive control. Lanes: 1 to 7 were positive samples. 


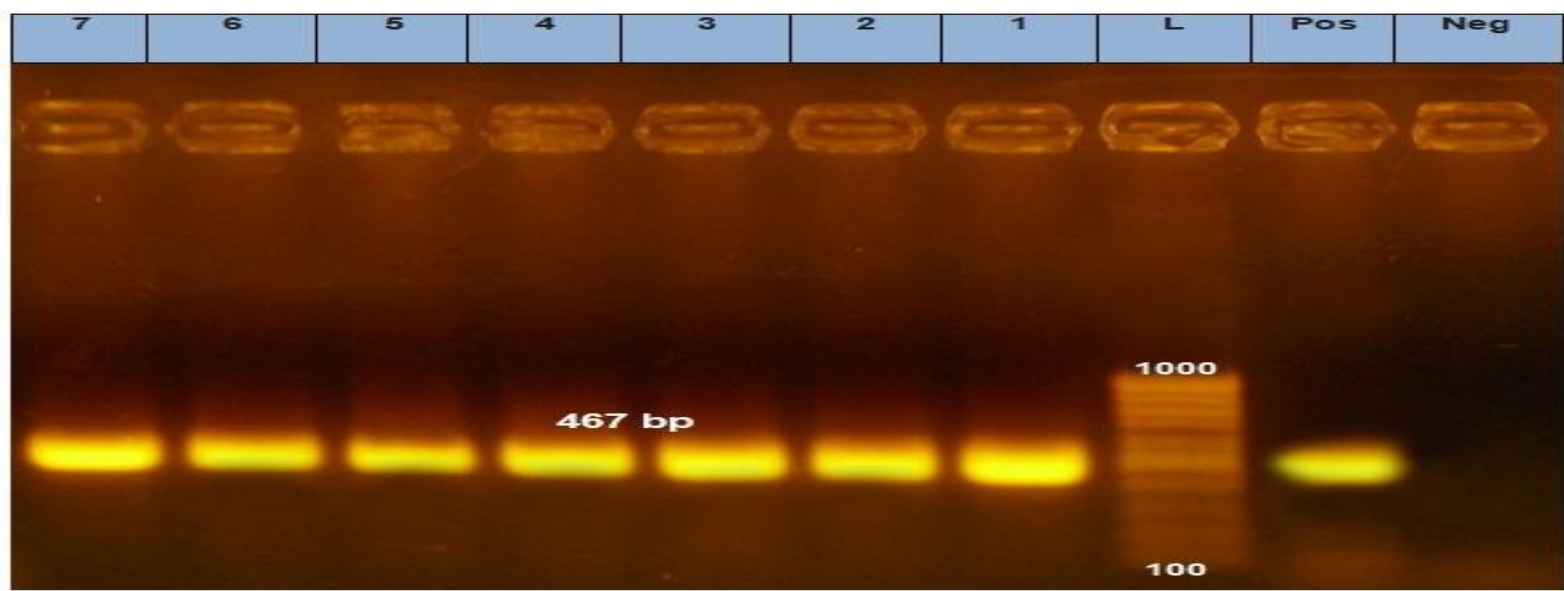

Figure (7): Agarose gel electrophoresis of PCR products for Salmonella isolates to detect $b c f C$ gene in genomic DNA. Lane L: 100-1000 bp DNA ladder. Neg: Negative control, Pos: Positive control. Lanes: 1 to 7 were positive samples.

In this study 3 migratory bird species (Common Teal, Mallard and Shoveler) were positive for Salmonella in Dakahlia and Damietta governorates along Lake Manzala. Four Salmonella serotypes were reported. Seven virulence genes were recorded in all isolates. Multidrug resistance was present in 3 Salmonella serotypes mean while one isolate ( $S$. Montevideo) showed no resistance (Table, 6).

Table 6: collective data of the positive bird species for Salmonella isolation, resistant antimicrobial agents and Salmonella virulence genes.

\begin{tabular}{|c|c|c|c|c|c|c|c|c|c|c|}
\hline \multirow{2}{*}{$\begin{array}{c}\text { Bird } \\
\text { species }\end{array}$} & \multirow{2}{*}{$\begin{array}{c}\text { Site of } \\
\text { collection }\end{array}$} & \multirow[t]{2}{*}{ Isolated Serotype } & \multirow{2}{*}{$\begin{array}{c}\text { Resistant } \\
\text { antimicrobial } \\
\text { agents } \\
\end{array}$} & \multicolumn{7}{|c|}{ Salmonella virulence genes } \\
\hline & & & & $\operatorname{invA}$ & $\operatorname{sop} B$ & $m g t C$ & $b c f \mathrm{C}$ & $\operatorname{spv} \mathrm{C}$ & $\operatorname{fim} \mathbf{H}$ & fim $\mathrm{A}$ \\
\hline $\begin{array}{c}\text { Common } \\
\text { Teal }\end{array}$ & Dakahlia & S. Bardo & $\begin{array}{c}\text { AMP* } \\
\text { CIP } \\
\text { ENR } \\
\text { N } \\
\text { E } \\
\text { C T } \\
\text { DO } \\
\text { TE }\end{array}$ & + & + & + & + & + & + & + \\
\hline $\begin{array}{c}\text { Common } \\
\text { Teal } \\
\end{array}$ & Damietta & S. Montevideo & - & + & + & + & + & + & + & + \\
\hline Mallard & Damietta & S. Kentucky & $\begin{array}{l}\text { AMP } \\
\text { CIP } \\
\text { ENR } \\
\text { LEV }\end{array}$ & + & + & + & + & + & + & + \\
\hline Shoveler & Damietta & $S$. Typhimurium & $\begin{array}{c}\text { AMP } \\
\text { CIP } \\
\text { ENR } \\
\text { NOR } \\
\text { TE }\end{array}$ & + & + & + & + & + & + & + \\
\hline
\end{tabular}

*Ciprofloxacin (CIP), Enrofloxacin (ENR), Norfloxacin (NOR), Levofloxacin (LEV), Ampicillin - sulbactam (AMP), Tetracycline (TE), Doxycyclin (DO), Erythromycin (E), Neomycin (N) and Colistin sulphate (CT).

\section{DISCUSSION}

Salmonella is one of the most common zoonotic bacteria that cause public health threat and sever losses to poultry industry (Faruq et al., 2016).

The migratory birds are flying across national and intercontinental borders, they can become long range vectors for Salmonella (Georgopoulou and Tsiouris, 2008), during the migration period, the birds immune system is weakened due to stress of migration that contributing to disease spreading and latent infections can be occurred (Altizer et al., 2011). Many serotypes of the genus Salmonella were able to survive form weeks to months in poultry litter, wild bird feces, soil and dust particles (Berchieri Junior and Freitas Neto, 2009). This explained the obtaining results in this study where Salmonella was isolated from 6 species of 100 migratory birds [Shoveler (6), Common Teal (60), Pintail (11), Mallard (14), Common Coot (4) 
and Wigeon (5)] in winter season along Manzala Lake in Dakahlia and Damietta Governorates in Egypt. Seven Salmonellae were isolated with a percentage of $(7 \%)$; 5 isolates (4 S. Bardo and one $S$. Montevideo) were reported from Common Teal with a percentage of $(8.3 \%)$, one S. Kentucky isolate from Mallard with a percentage of $(7.1 \%)$ and one $S$. Typhimurium isolate from Shoveler with a percentage of $(6.3 \%)$.

The incidence of Salmonella isolation in this study was $(7 \%)$ and it considered higher from other studies conducted by Fallacara et al. (2004) who reported 8 Salmonella isolates from 450 free living water fowl in Columbus Zoo, Ohio with a percentage of (1.7\%), Rodríguez et al. (2018) who isolated 4 Salmonella serovars ( $S$. Typhimurium, $S$. Schwarzengrund, $S$. enterica subsp. I [4,12: i: -] and $S$. enterica subsp. IIIb [60: r: e, n, x, z15]) with a percentage of (1\%) from cloacal swabs of 599 free-living waterfowl from April 2014 to July 2016, Fallacara et al. (2001) reported a lower incidence of Salmonella $(0.2 \%)$ from free living water fowl and Foti et al. (2011) who isolated $2 \mathrm{~S}$. bongori isolates from faecal swabs and internal organs of migratory birds in Italy.

Several researchers such as Fallacara et al. (2001), Fallacara et al. (2004), Foti et al. (2011) and Rodríguez et al. (2018) isolated Salmonella from cloacal swabs collected from free living water fowl birds but in this study Salmonella was isolated from internal organs of these birds with a higher percentage. This might be attributed to the intermittent shedding of Salmonella.

In the present study; Pintail, Common Coot and Wigeon birds were negative for Salmonella isolation and this agreed with Antilles et al. (2015) who didn't isolate Salmonella from cloacal swabs of the same birds that collected from north-east Spain during the hunting season (October to February) from the end of 2008 to 2011 .

In the present study, the examined migratory birds may act as reservoirs for antimicrobial resistant Salmonella pathogen and can be transmitted by direct contact with food-producing animals, human waste and with species that can act as vectors (insects, rodents, and other birds).

Recently the misuse of antimicrobial agents resulted in multidrug resistance of Salmonella particularly in the developing countries (Faruq et al., 2016). Two S. Bardo isolates, S. Typhimurium and S. Kentucky in this study showed multi- drug resistance that raise an alert for the need and importance of a surveillance programs to avoid Salmonella infection. These obtaining results were agreed to a great extent with (Palmgren et al., 1997) who reported multidrugresistant strains of $S$. Typhimurium isolated from migratory birds in Sweden.
The obtaining results in the present study showed that $S$. Montevideo and two $S$. Bardo isolates showed higher sensitivity to most of the used antimicrobial agents and these nearly agreed with Grigar et al. (2017) who reported that $S$. Thompson and $S$. Braenderup isolated from waterfowl along the Texas Gulf coast were susceptible to amoxicillin/clavulanic acid, ampicillin, azithromycin, cefoxitin, ceftiofur, ceftriaxone, chloramphenicol, ciprofloxacin, gentamicin, nalidixic acid, streptomycin, sulfisoxazole, tetracycline and trimethoprim/ sulfamethoxazole.

Salmonella pathogenesis is controlled by a series of genes that responsible for invasion (Porter et al., 1997), colonization (Thiagarajan et al., 1996), and spread (Libby et al., 1997) within the host. The host adaptation of Salmonella was influenced by the distribution of fimbrial and non fimbrial adhesins (Baumler et al., 1997). The virulence of Salmonella isolates was assessed using PCR technique for the detection of invA, sop B, $m g t \mathrm{C}, b c f \mathrm{C}, s p v \mathrm{C}, f i m \mathrm{H}$ and fim A virulence genes using PCR technique; all genes were recorded in all Salmonella isolates. Some researchers such as Krawiec et al. (2015) reported inv $\mathrm{A}$ and sop B genes with a percentage of (100\%) and $(94.45 \%)$ respectively in Salmonella isolated from aquatic wild birds and free living birds in Poland, Hudson et al. (2000) isolated Salmonella from non-domestic birds in Southeastern United States and all isolates contained the invasion gene inv A but 17 isolates contained the $s p v \mathrm{C}$ gene.

The findings in this study suggest that migratory birds considered as an important source of Salmonella strains that can contaminate the environment around poultry farms and produce a new endemic area of Salmonellosis that adversely affect poultry industry leading to sever economic losses. Also migratory birds may considered as a source of Salmonella strains that are pathogenic to people.

\section{CONCLUSION}

In conclusion: Identification and antimicrobial resistance of Salmonella isolated from migratory birds is necessary to the early detection of zoonotic strains and also to evaluate the emergence of new resistance strains. Salmonella was isolated from two Egyptian Governorates along Manzala Lake with an incidence of $(7 \%) ; S$. Bardo, $S$. Montevideo, $S$. Kentucky and $S$. Typhimurium. Some of the isolated Salmonellae showed multi- drug resistance. Several virulence genes such as $i n v \mathrm{~A}, \operatorname{sop} \mathrm{B}, m g t \mathrm{C}, b c f \mathrm{C}$, $s p v \mathrm{C}, \operatorname{fim} \mathrm{H}$ and $f i m \mathrm{~A}$ were detected in all of recorded Salmonella isolates.

Further studies and surveillance programs should be conducted to investigate Salmonella strains isolated from humans residing in fishing, backyards and poultry farms to provide an overview about the 
transmission processes of Salmonella from migratory birds to human and studying the migration pattern that will be useful in the prediction of future outbreaks due to emerging zoonotic pathogens.

Finally, it's necessary to apply control measures and biosecurity programs in poultry farms to avoid any risk of Salmonella transmission and other zoonotic diseases via migratory birds. Also people that hunt, cook and eat migratory birds should be aware with the risk involved from such birds.

\section{REFERENCES}

Abulreesh, H.H.; Goulder, R. and Scott, G.W. (2007): Wild birds and human pathogens in the context of ringing and migration, Ringing \& Migration, 23(4): 193-200.

Altizer, S.; Bartel, R. and Han, B.A. (2011): Animal migration and infectious disease risk. Science, 331:296-302.

Antilles, N.; Sanglas, A. and Cerda-Cuellar, M. (2015): Free-living Waterfowl as a Source of Zoonotic Bacteria in a Dense Wild Bird Population Area in Northeastern Spain. Transboundary and Emerging Diseases. 62 (2015) 516-521.

Baha el Din, S. and Salma, W. (1984): Water bird migration study at Zaranik, Sinai: 2-24, September 1982. Courser, I, 28- 43.

Baumler, A.; Gilde, J.; Tsolis, R.M.; Van Der Velden, A.W.M.; Ahmer, B.M.M. and Heffron, F. (1997): Contribution of horizontal gene transfer and deletion events to development of distinctive patterns of fimbrial operons during evolution of Salmonella serotypes. J. Bacteriol. 179: 317-322.

Bennasar, A.G.; Luna, D.; Cabrer, B. and Lalucat, J. (2000): Rapid identification of $S$. Typhimurium, $S$. Enteritidis and $S$. Virchow isolates by polymerase chain reaction based fingerprinting methods. Int. Microbiol., 3: 31-38.

Berchieri Junior, A. and Freitas Neto, O.C. (2009): Salmonellosis. In: Berchieri Junior, A., Silva, E.N., Di Fabio, J., Sesti, L., Zuanaze, M.A.F., editors. Bird diseases $2^{\text {nd }}$ ed. Campinas: FACTA; 2009. p. 435-454.

Bianki, V.V. and Dobrynina, I.N. (1997): Anseriformes, Dabbling ducks. In: Pavlov, D.S. (series ed.): Migrations of Birds of eastern Europe and Northern Asia. Nauka, Moscow.

CLSI (2016): Clinical and Laboratory standard Institute, M02- A12, M07- A10, and M11- A8.

Cohen, H.J.; Mechanda, S.M. and Lin, W. (1996): PCR amplification of the fim $\mathrm{A}$ gene sequence of Salmonella Typhimurium, a specific method for detection of Salmonella spp. Appl Environ Microbiol., 62(12):4303-4308.
Cruickshank, R.; Duguid, J.P.; Marmio, B.P. and Swain, R.H.A. (1975): Medical Microbiology. The practice of Medical Microbiology. $12^{\text {th }}$ Ed. Vol II Churchill Living stone, Edinburgh, London and New York., 2: 170- 188.

Delany, S.; Veen, J. and Clark, J.A. (2006): Urgent preliminary assessment of ornithological data relevant to the spread of Avian Influenza in Europe. Report to the European Commission. Study contract: 07010401/2005/425926/ MAR/B4. Authors: Atkinson, P.W., Clark, J.A., Delany, S., Diagana, C.H., du Feu, C., Fiedler, W., Fransson, T., Gaulthier-Clerc, M., Grantham, M.J., Gschweng, M., Hagemeijer, W., Helmink, T., Johnson, A., Khomenko, S., Martakis, G., Overdijk, O., Robinson, R.A., Solokha, A., Spina, F., Sylla, S.I., Veen, J. and Visser, D.

Fallacara, D.M.; Monahan, C.M.; Morishita, T.Y.; Bremer, C.A. and Wack, P.F. (2004): Survey of parasites and bacterial pathogens from freeliving waterfowl in zoological settings. Avian Dis. 48, 759-767.

Fallacara, D.M.; Monahan, C.M.; Morishita, T.Y. and Wack, R.F. (2001): Fecal shedding and antimicrobial susceptibility of selected bacterial pathogens and a survey of intestinal parasites in free-living waterfowl. Avian Dis.; 45(1): 128-135.

Faruq, A.A.; Hassan, M.M.; Uddin, M.M.; Rahman, M.L.; Rakib, T.M.; Alam, M. and Islam, A. (2016): Prevalence and multidrug resistance pattern of Salmonella isolated from resident wild birds of Bangladesh. Int J One Health; 2: 35-41.

Finegold, S.M. and Martin, E.T. (1982): Diagnostic Microbiology. $6^{\text {th }}$ ed., The C.V. Mosby Company, St. Louis, Toronto, London.

Foti, M.; Rinaldo, D.; Guercio, A.; Giacopello, C.; Aleo, A.; De Leo, F.; Fisichella, V. and Mammina, C. (2011): Pathogenic microorganisms carried by migratory birds passing through the territory of the island of Ustica, Sicily (Italy). Avian Pathology, 40 (4), 405-409.

Gast, R.K. and Beard, C.W. (1992): Evaluation of a chick mortality model for predicting the consequences of Salmonella Enteritidis infections in laying hens. Poult Sci, 71(2): 281-287.

Georgopoulou, I. and Tsiouris, V. (2008): The potential role of migratory birds in the transmission of zoonoses. Veterinaria Italiana, 44 (4): 671-677.

Goodman, S.M. and Meininger, P.L. (1989): The birds of Egypt. Oxford University press, New York; 1989. p. 158- 224.

Grigar, M.K.; Cummings, K.J. and Rankin, S.C. (2017): Prevalence of Salmonella among waterfowl along the Texas Gulf coast. Zoonoses Public Health, 64: 689-692. 
Hilbert, F.; Smulders, F.J.M.; Chopra-Dewasthaly, $R$. and Paulsen, P. (2012): Salmonella in the wildlife-human interface, Food Research International, 45 (2): 603-608.

Hojati, Z.; Zamanzad, B.; Hashemzadeh, M.; Molaie, $R$. and Gholipour, A. (2013): Detection of FimH Gene in Uropathogenic Escherichia coli Strains Isolated from Patients with Urinary Tract Infection. Jundishapur J. Microbiol., 8(2): e17520.

Hoop, R.K. and Pospischill, A. (1993): Bacteriological, serological, histological and immunohistochemical findings in laying hens with naturally acquired $S$. Entertidis phage type 4 infection. Vet Rec, 133(16): 391-393.

Hubalek, Z. (2004): an annotated chick list of pathogenic micro-organisms associated with migratory birds. J. wild life Dis., 40: 639- 659.

Hudson, C.R.; Quist, C.; D. Lee, M.; Keyes, K.; Dodson, S.V.; Morales, C.; Sanchez, S.; White, G.D. and Maurer, J. (2000): Genetic Relatedness of Salmonella Isolates from Nondomestic Birds in Southeastern United States. Journal of Clinical Microbiology, 38 (5): 1860-1865.

Huehn, S.; La Ragione, R.M.; Anjum, M.; Saunders, M.; Woodward, M.J.; Bunge, C.; Helmuth, R.; Hauser, E.; Guerra, B.; Beutlich, J.; Brisabois, A.; Peters, T.; Svensson, L.; Madajczak, G.; Litrup, E.; Imre, A.; HerreraLeon, S.; Mevius, D.; Newell, D.G. and Malorny, B. (2010): Virulotyping and antimicrobial resistance typing of Salmonella enterica serovars relevant to human health in Europe. Foodborne Pathogens, 7: 523-535.

ISO 6579-1 (2017): Microbiology of food and animal feeding stuff- horizontal method for detection of enumeration and serotyping Salmonella SPP. International standard. (First ed., 022017).

Jourdain, E.; Gauthier-Clerc, M.; Bicout, D. and Sabatier, P. (2007): Bird Migration Routes and Risk for Pathogen Dispersion into Western Mediterranean Wetlands. Emerging Infectious diseases, 13: 365- 372.

Kauffman, F. (1974): Serological diagnosis of Salmonella species. Kauffman white scheme Minkagaord, Copenhagen, Denmark.

Krawiec, M.; Kuczkowski, M.; Kruszewicz, A. and Wieliczko, A. (2015): Prevalence and genetic characteristics of Salmonella in free-living birds in Poland. BMC Veterinary Research, 11: 15 .

Libby, S.J.; Adams, L.G.; Ficht, T.A.; Allen, C.; Whitford, H.A.; Buchmeir, A.A.; Bossie, A. and Guiney, D.G. (1997): The spv genes on the Salmonella Dublin virulence plasmid are required for severe enteritis and systemic infection in the natural host. Infect. Immun. 65: 1786-1792.
Lutful Kabir, S.M. (2010): Avian Colibacillosis and Salmonellosis: a closer look at epidemiology, pathogenesis, diagnosis, control and public health concerns. Int $\mathrm{J}$ Environ Res Public Health 7:89-114.

McClure (1998): Migration and Survival of the Birds of Asia. White Lotus Press, Thailand.

Meininger, P.L. and Mullie, W.C. (1981): The significance of Egyptian wetlands for wintering water birds. The Holy Land conservation fund, New York.

Millán, J.; Aduriz, G.; Moreno, B.; Juste, R.A. and Barral, M. (2004): Salmonella isolates from wild birds and mammals in the Basque Country (Spain). Rev Sci. Tech., 23, 905-911.

Nuttall, P.A. (1997): Viruses, bacteria, and fungi of birds. In: Clayton DH, Moore J, editors. Hosteparasite evolution. Oxford, UK: University Press; 1997. p. 271-302.

OIE (2004): Manuals of standards for diagnostic test and vaccine. 4 th. France, pp. 446-456.

Olivera, S.D.; Rodenbusch, C.R.; Ce, M.C.; Rocha, S.L.S. and Canal, C.W. (2003): Evaluation of selective and non-selective enrichment PCR procedures for Salmonella detection. Lett. Appl. Microbiol., 36: 217-221.

Palmgren, H.; Sellin, M.; Bergstrom, S. and Olsen, B. (1997): Enteropathogenic bacteria in migrating birds arriving in Sweden. Scandinavian Journal of Infectious Diseases, 29: 565-568.

Porter, S.B. and Curtiss, R. (1997): Effect of inv mutations on Salmonella virulence and colonization in 1-day-old white Leghorn chicks. Avian Dis. 41: 45-57.

Rodríguez, F.I.; Osinalde, J.M.; Gómez, S.C.; Pulido, D.G.; Caffer, M.I.; Nicolau, F.C. and Bueno, D.J. (2018): Prevalence, antimicrobial resistance profile and comparison of selective plating media for the isolation of Salmonella spp. in free ranging waterfowl from Entre Rios, Argentina. Poult Sci.,97(9): 3043-3049.

Scott, D.A. and Rose, P.M. (1996): Atlas of Anatidae Populations in Africa and Western Eurasia. Wetlands International Publication 41.

Silva, M.A.; Marvulo, M.F.V.; Mota, R.A. and Silva, J.C.R. (2010): The role of order Ciconiiformes in the epidemiological chain of Salmonella spp. for public health and biological diversity conservation, Pesquisa Veterin'aria Brasileira, 30 (7): 573-580.

Su, Y.C.; Yu, C.Y; Lin, J.L.; Lai, J.M.; Chen, S.W.; Tu, P.C and Chu, C. (2011): Emergence of Salmonella Enterica serovar Potsdam as a major serovar in water fowl hatcheries and chicken eggs. Avian Dis.; 55(2): 217-222.

Thiagarajan, D.; Saeed, M.; Turek, J. and Asem, E. (1996): In vitro attachment and invasion of chicken ovarian granulosa cells by Salmonella 
Enteritidis phage type 8. Infect. Immun. 64: 5015-5021.

Tizard, I. (2004): Salmonellosis in wild birds. Semin. Avian Exot. Pet Med., 13: 50-66.

Tsiodras, S.; Kelesidis, T.; Kelesidis, I.; Bauchinger, $U$. and Falagas, M.E. (2008): Human infections associated with wild birds. Journal of Infection, 56 (2): 83-98.

Veen, J.; Yurlov, A.K.; Delany, S.N.; Mihantiev, A.I.; Selivanova, M.A. and Boere, G.C. (2005): An atlas of movements of Southwest Siberian waterbirds. Wetlands International, Wageningen, The Netherlands.

Wernham, C.; Toms, M.; Marchant, J.; Clark, J.; Siriwardena, G. and Baillie, S. (2002): The Migration Atlas: movements of the birds of Britain and Ireland. T. \& A.D. Poyser, London.

WHO (2007): WHO Collaborating Centre for Reference and Research on Salmonella: Antigenic Formulae of the Salmonella Serovars, 2007 9th edition, Patrick A.D. Grimont, François-Xavier Weill.

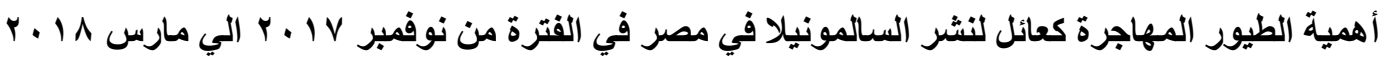

$$
\text { نهال محمود نبيل ، /حلام السيل يونس }
$$

E-mail: nehal_nabil84@yahoo.com Assiut University web-site: www.aun.edu.eg

تلعب الطيور المهاجرة دور المهما في نقل الامر اض المشتركة خاصة السالمونيلا والتي تسبب حالات مرضية في الانسان والحيوان

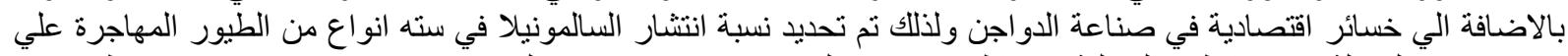

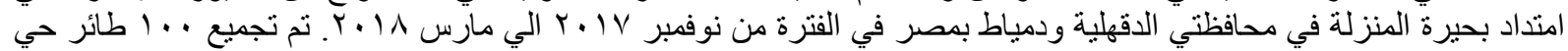

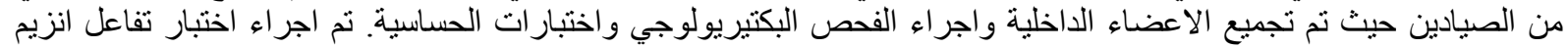

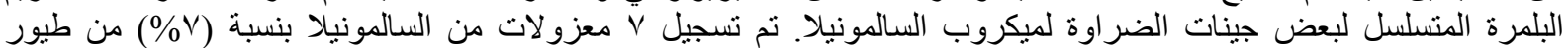

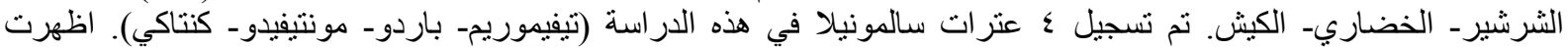

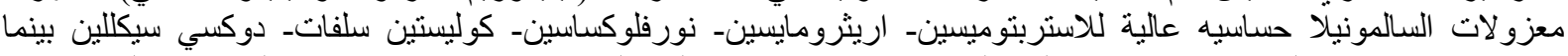

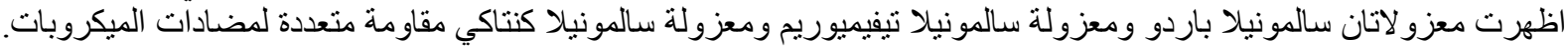

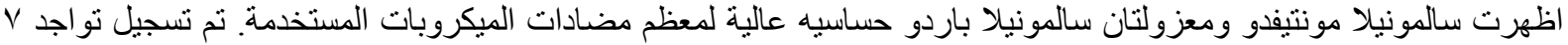

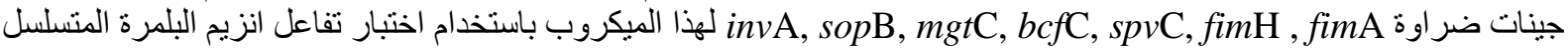
حيث تو اجدت هذه الجينات في جميع معزو لات السالمونيلا بهذه الدر اسة. 